Revista Brasileira de Higiene e Sanidade Animal Brazilian Journal of Hygiene and Animal Sanity ISSN: $1981-2965$

\title{
Clinical, diagnostic and therapeutic approach of uveodermatologic syndrome in dogs: a review
}

\author{
Abordagem clínica, diagnóstica e terapêutica da síndrome uveodermatológica em cães: \\ uma revisão
}

\section{Alexandre Tavares Camelo Oliveira ${ }^{1}$, Ana Raquel Fontenele de Oliveira ${ }^{2}$, Isadora Lobão Torres Santiago ${ }^{3}$, Yvyna Byanca Simões de Lima ${ }^{4}$, Tiago Cunha Ferreira ${ }^{5}$}

\begin{abstract}
Canine uveodermatologic syndrome is an autoimmune disease that leads to the appearance of ophthalmic and dermatological signs, such as bilateral panuveitis, vitiligo, leukotrichia, alopecia and ulcerations. Due to the lack of information about the uveodermatologic syndrome, the objective of this work is to carry out a systematic review on the main aspects of the disease, alerting the veterinarian about its occurrence and the importance of its early diagnosis. Despite the rare reports within the small animal clinic, it is believed that dogs of the Akita breed may be predisposed by the number of reported cases, although there are several records with other breeds in the literature. The diagnosis is usually late, due to the fact that the eye lesions appear about a month before the cutaneous lesions, and involves the clinical reasoning of the veterinarian in association with the performance of histopathological exams of the lesions, which present inflammatory histio-lymphocitic infiltrates and disorganization of basal layer. The treatment is based on immunosuppression, with corticosteroids or other similar drugs, such as azathioprine and cyclosporine, continuing from the diagnosis until the disappearance of clinical signs and maintenance at low doses or in association with other immunomodulators.
\end{abstract}

Key-words: autoimmune diseases, uveitis, vitiligo, melanin, canine skin diseases.

Resumo. A síndrome uveodermatológica canina é uma doença auto-imune que leva ao aparecimento de sinais oftálmicos e dermatológicos, como panuveítes bilaterais, vitiligo, leucotriquia, alopecia e ulcerações. Devido à falta de informações acerca da síndrome uveodermatológica, o objetivo deste trabalho é realizar uma revisão sistemática sobre os principais aspectos da doença, alertando o médico veterinário sobre sua ocorrência e importância sobre seu diagnóstico precoce. Apesar dos raros relatos dentro da clínica de pequenos animais, acredita-se que cães da raça Akita possam ser predispostos pela quantidade de casos relatados, embora hajam diversos registros com outras raças na literatura. O diagnóstico é geralmente tardio, por conta que as lesões oculares aparecem cerca de um mês antes das lesões tegumentares, e envolve o raciocínio clínico do médico veterinário em associação com a realização de exames histopatológicos das lesões, que apresentam infiltrados inflamatórios histiolinfocitários e desorganização da camada basal do epitélio. O tratamento baseia-se na imunossupressão, com corticóides ou outros fármacos análogos, como azatioprina e ciclosporina, do diagnóstico até o desaparecimento dos sinais clínicos e manutenção com doses baixas ou em associação a outros imunomoduladores.

Palavras-chave: doenças autoimunes, uveíte, vitiligo, melanina, dermatopatias caninas.

Corresponding authors Email: tiago.cunha@uece.br

Recebido em 10.01.2020. Aceito em 30.06.2020

http://dx.doi.org/10.5935/1981-2965.20200022

${ }^{1}$ Graduando em Medicina Veterinária, Faculdade de Veterinária (FAVET), Universidade Estadual do Ceará (UECE), alexandretco@ hotmail.com.

${ }^{1}$ Graduando em Medicina Veterinária, Faculdade de Veterinária (FAVET), Universidade Estadual do Ceará (UECE), anaraquel_fo@hotmail.com. 
${ }^{1}$ Graduando em Medicina Veterinária, Faculdade de Veterinária (FAVET), Universidade Estadual do Ceará (UECE), isadoralobaao@gmail.com.

${ }^{1}$ Graduando em Medicina Veterinária, Faculdade de Veterinária (FAVET), Universidade Estadual do Ceará (UECE), yvynabyanca@ hotmail.com.

${ }^{1}$ Professor de Medicina Veterinária, Faculdade de Veterinária (FAVET), Universidade Estadual do Ceará (UECE), tiago.cunha@uece.br

\section{Introduction}

Uveodermatologic Syndrome

(UDS) is a rare autoimmune disease that affects both the skin and the eyes of predisposed dogs (ZARFOSS et al., 2018).

This immunological disorder resembles Vogt-Koyanagi-Harada (VKH) syndrome in humans (O'Keefe \& Rao, 2017), however, the rare occurrence of neurological signs, such as meningitis, in this species (ZARFOSS et al., 2018) made such nomenclature inappropriate, with UDS being a more proper designation.

The first cases in dogs were described in Japan in 1977 involving two Akita dogs (ASAKURA et. al., 1977). Since then, other cases of the disease have been reported in different breeds (HORIKAWA et al., 2013; ZARFOSS et al., 2018). Although there is a lack of genetic screening for UDS risk in Akita, it is believed that this breed is predisposed to its occurrence, representing up to $80 \%$ of reported cases (ANGLES et al., 2005). In affected dogs, it is thought that a compromised immune tolerance against proteins of the tyrosinase family triggers a
Th-1 autoimmune attack in the uvea and the skin, causing ocular and dermatological signs (ANGLES et al., 2005; YAMAKI et al., 2005).

Clinically, this disease presents with panuveitis, vitiligo and leukotrichia, with ophthalmic signs usually preceding dermatological signs (BLACKWOOD et al., 2011; KIBAR et al., 2014). The clinical diagnosis is based on the appearance of unilateral or bilateral uveitis and skin ulcerations unresponsive to antibiotics and responsive to corticosteroid therapy (SIGLE et al., 2006; HORIKAWA et al., 2013; ZARFOSS et al., 2018). Early diagnosis for UDS is difficult, since uveitis has several causes and it would be necessary to rule it out before reaching an autoimmunity diagnosis (GELATT, 2014; MASSA et al., 2002).

Considering the fact that currently there is still not much knowledge about the etiology, cause and pathogenesis of this condition (KANG et al., 2014), this study aims to gather relevant information about the disease, in addition to alerting veterinarians working in the clinic of small 
animals on the importance of the domain of basic semiology associated with the performance of complementary exams for the correct diagnosis of this skin disease.

\section{Epidemiology and Immunopathogenesis}

Many cases have been described in other countries worldwide (Table 1), since the first described reports of UDS in dogs of Akita breed in Japan (ASAKURA et al., 1977).

Purebred dogs have been shown to be more susceptible, with Akita dogs being more predisposed and with a high incidence of the disease, which may suggest the presence of genetic markers (ANGLES et al., 2005).

Table 1. Epidemiology of dogs with UDS reported in literature.

\begin{tabular}{llll}
\hline Breed & Age (Years) & Sex & References \\
\hline American Akita & $1.1-5.4(3.4 \pm 1.4)$ & Male/Female & ANGLES et al., 2006. \\
Rat Terrier & 4 & Male & BLACKWOOD et al., 2011. \\
Akita Inu & 1 & Male & CARMOZINE et al., 2017. \\
Akita Inu & $5.0-11.0(8.0)$ & Female & CARTER et al., 2005. \\
Akita Inu & 1 & Female & COTTELLL e BARNETT, 1987. \\
Cocker & 2.5 & Male & GODOY et al., 2003. \\
Spaniel/Poodle & & Female & HERRERA et al., 1998. \\
\hline Dachshund & 3 & Male & HORIKAWA et al., 2013. \\
Border Collie & 3.0 & Female & KANG et al., 2014. \\
Poodle & 5 & Male & KIBAR et al., 2014. \\
Siberian Husky & 1.5 & Male & LAUS et al., 2004. \\
Brazilian Mastiff & 5 & Female & LIMA et al., 2013. \\
Akita Inu & 4 & Male/Female & MASSA et al., 2002. \\
Golden Retriev. & $6.2 \pm 3.6$ & Female & PYE, 2009. \\
Akita Inu & 8 & Female & SIGLE et al., 2006. \\
Siberian Husky & 7 & Male & SUÁREZ et al., 2012. \\
Collie & 8.5 & Male & TRBOLOVA et al., 2003. \\
Rottweiler & 3.5 & $0.66-1$ & YAMAKI et al., 2005. \\
Akita Inu & 6.5 & ZARFOSS et al., 2018. \\
Labrador Retriev. & & & \\
\hline & & & \\
\hline
\end{tabular}

However, no veterinary study has been carried out to identify genes or proteins that could be breed specific and related to UDS (HORIKAWA et al., 
2013). The small number of diagnosed cases in the veterinary routine makes this screening harder, as well as hamper the establishment of relationship between animals and thus propose a hereditary predisposition (BLACKWOOD et al., 2011).

Immunological and histopathological studies suggest that VKH syndrome in humans is an inflammatory and autoimmune condition mediated by CD4 + T cells that mark melanocytes. This process triggers the production of cytokines, such as interleukin (IL) 17 and IL-23, in individuals with compromised immune tolerance to melanocytes (BOYD et al., 2001; O'KEEFE \& RAO, 2017).

However, when it comes to UDS, the etiology is still unknown, and the susceptibility to the development of the disease is associated with both genetic and immunological factors.

The proteins of the tyrosinase family are exclusively expressed by melanocytes and are used in the production of melanin by an enzymatic catalysis process (YAMAKI et al., 2000). These peptides were used experimentally in an immunization protocol for two Akita dogs in order to monitor the development of the vaccine immune response. In the end, both animals developed bilateral severe anterior uveitis after three weeks with subsequent appearance of alopecic and vitiligo lesions in the nasal planum and eyelids after 8 weeks. Upon histological examination, these changes showed extensive inflammatory infiltrates consistent with histological analysis of lesions caused by the VKH syndrome (YAMAKI et al., 2005), characterizing UDS. It was also seen that B lymphocytes were the most prevalent inflammatory cells in these histological evaluations (SIGLE et al., 2006), which highlights the possible role of antibodies in UDS development.

It is also discussed about possible genetic and hereditary involvement in the disease. Studies carried out in the United States and the United Kingdom have shown that Akita dogs in the region are predisposed to the occurrence of autoimmune diseases because they descend directly from a small number of Japanese Akita Inu imported and reproduced through inbreeding (COTTELLL \& BARNETT, 1987; RHODEN, 2002). It is believed that the current population of this breed comes almost exclusively from these few specimens, stimulating the appearance of several autoimmune diseases due to inbreeding; among them, UDS, representing $4.1 \%$ of the cases of autoimmune diseases (ANGLES et al., 2005).

In addition, some American Akita dogs showed a considerable increase in the expression of the dog leukocyte antigen 
(DLA) DQA1 / 00201 in affected individuals in relation to healthy animals. These dogs are considered predisposed to UDS and may develop the clinical disease, if the necessary stimulus for autoimmunity triggers (ANGLES et al., 2005).

In humans, the possibility of the appearance of VKH syndrome associated with previous viral exposure is reported, suggesting that environmental factors, such as viruses, may stimulate clinical disease in these already predisposed individuals (O'KEEFE \& RAO, 2017). However, insufficient data were found to correlate environmental factors with the emergence of UDS in dogs. Regarding the immunopathology of UDS, melanocytes in the eyes, skin and central nervous system (CNS) have the same embryonic origin and, therefore, these systems are the target of the disease (HERRERA \& DUCHENE, 1998; LAUS et al., 2004; BLACKWOOD et al., 2011; HORIKAWA et al., 2013). Sometimes the ocular signs precede the dermatological signs, with uveitis occurring about a month prior vitiligo lesions, although no studies on this fact have been carried out (SIGLE et al., 2006). In addition, it is also unknown why dogs do not have neurological damage. In a histopathological study, subarachnoid mononuclear inflammatory infiltrates were found in patients with spontaneous and induced UDS, but there were no signs of inflammation in gray matter or white matter (CARTER et al., 2005; YAMAKI et al., 2005). A summary of the proposed immune-mediated damage is shown in Figure 1.

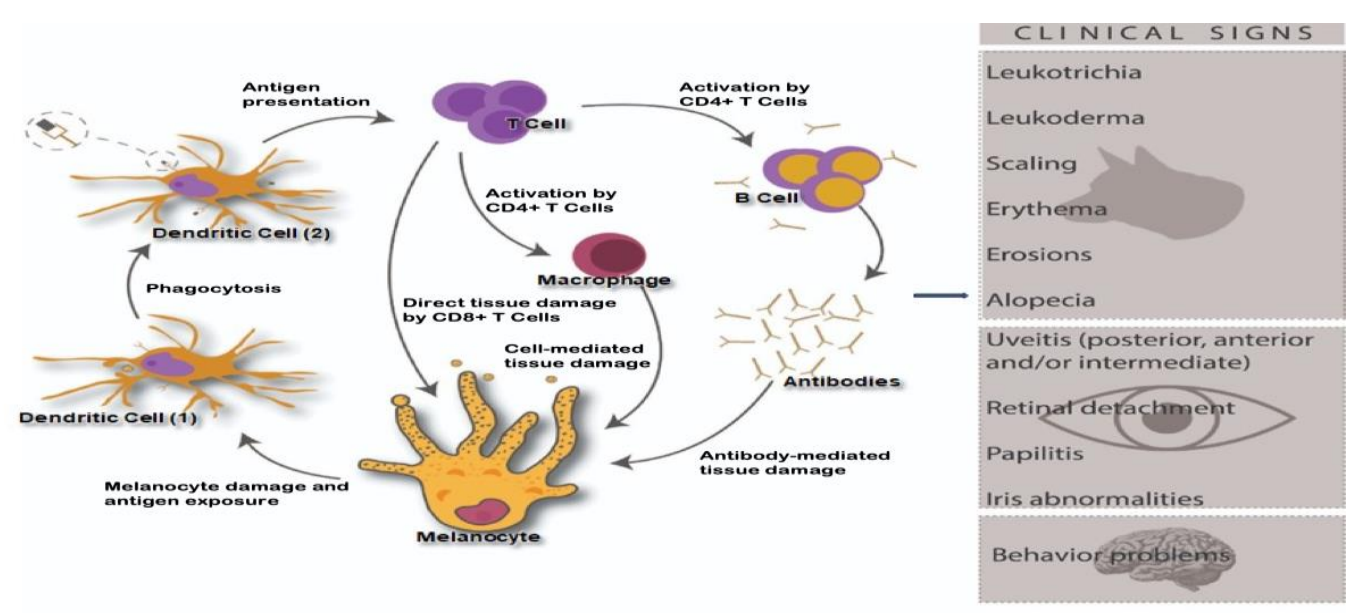

Figure 1. Loss of immune tolerance and development of autoimmune response against melanocytes. In (1) the dendritic cells phagocyte melanocytic antigen, process and expose the epitope in (2) to a naïve $T$ cell. As a result, the activation of immune response against melanocytes occurs, which culminates with tissue damage, leading to appearance of clinical signs; these are listed aside. Author source. 


\section{Clinical signs}

Dermatological signs include leukoderma, scaling, erythema, depigmentation, leukotrichia, alopecia and mucocutaneous erosions, which frequently are present as symmetrical lesions (ZARFOSS et al., 2018). These changes are observed around the nasal planum, mouth, eyelids and periocular region, in addition to, less frequently, scrotum, vulva, footpad and anus (TRBOLOVA et al., 2003). These conditions can be aggravated by the sun rays and the pruritus has different degrees, varying from absent to intense (HERRERA \& DUCHENE, 1998; THAM et al., 2019).

Dogs with UDS affected skin are shown in Figure 2.

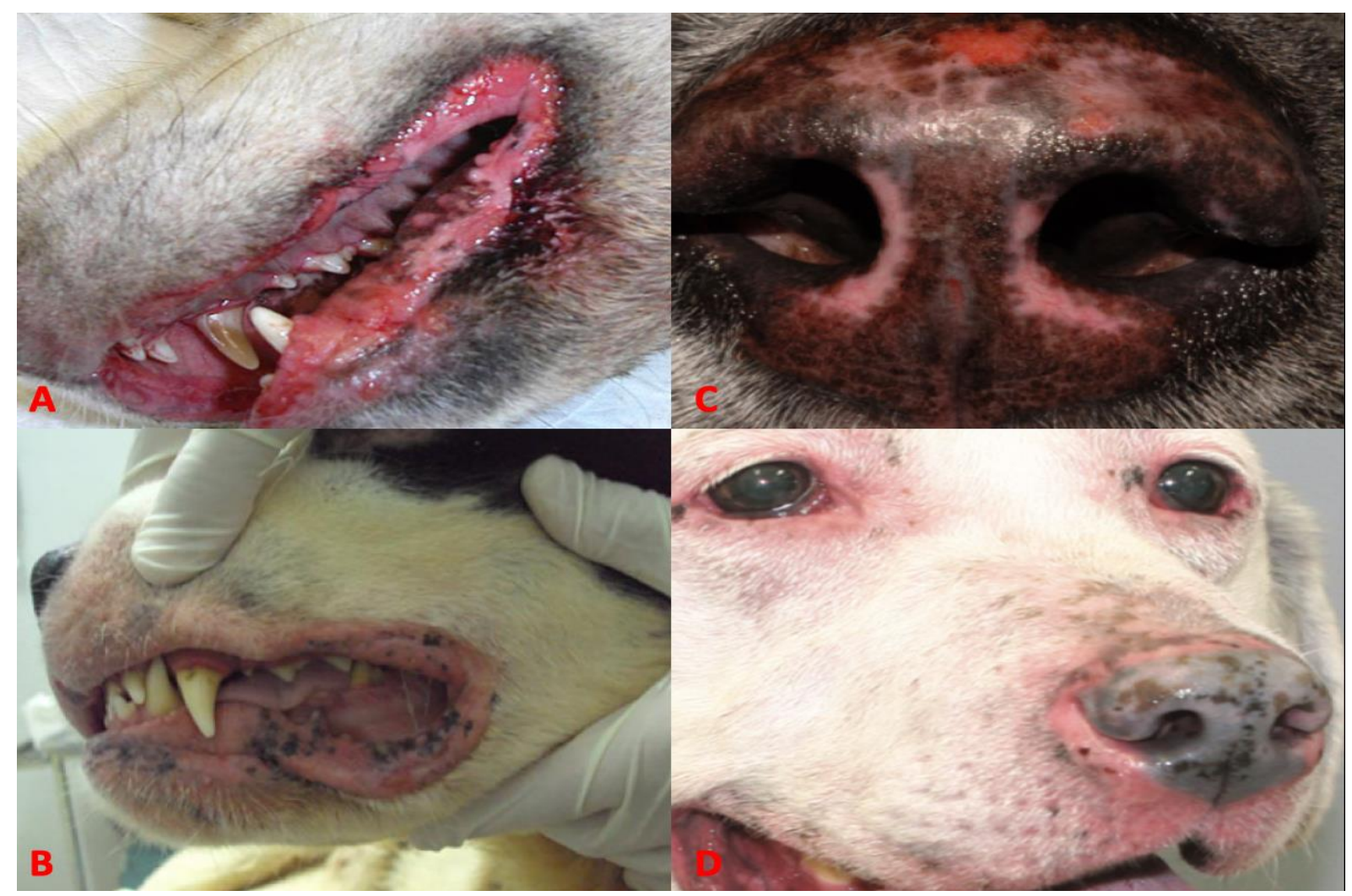

Figure 2. Dermatologic lesion patterns of dogs with UDS. (A) Severe erosive dermatitis of lips and gingivitis in Chow Chow breed (THAM et al., 2019). (B) Depigmentation, edema, alopecia and erosions of perilabial region in Saint Bernard breed (FONSECA-ALVES et al., 2014). (C) Focal erosions, depigmentation, erythema and loss of the normal nasal planum architecture in Akita-Inu breed (THAM et al., 2019). (D) Blepharitis, loss of nasal architecture, erythema and nasal depigmentation in Labrador breed with UDS (ZARFOSS et al., 2018).

Acute uveitis, characterized by diffuse choroiditis concomitant with exudative retinal detachments and papillitis comprises the most common ophthalmic alteration (GODOY et al., 2003). Animals may show signs of intraocular inflammation, depigmentation of the fundus and limbus, in addition to recurrent 
iridocyclitis (READ et al., 2001). Rashes, iris abnormalities, such as rubeosis iridis, iridal edema, synechia or pigment deposition in the anterior lens capsule), retinal detachment, choroidal depigmentation or chorioretinal infiltration, retinal degeneration and cataract are also present. In dogs, bilateral uveitis and anterior dispersion of the uveal pigment or choroidal depigmentation combined with dermatological abnormalities is highly suggestive of UDS.
There are cases in which ophthalmic and dermatological lesions appear simultaneously (ZARFOSS et al., 2018).

When late diagnosed, this syndrome can result in permanent blindness. The prognosis of visual function depends on the time since diagnosis and initiation of immunosuppressive treatment (FONSECA-ALVES et al., 2014). Some of the ophthalmic lesion patterns are shown in Figure 3.

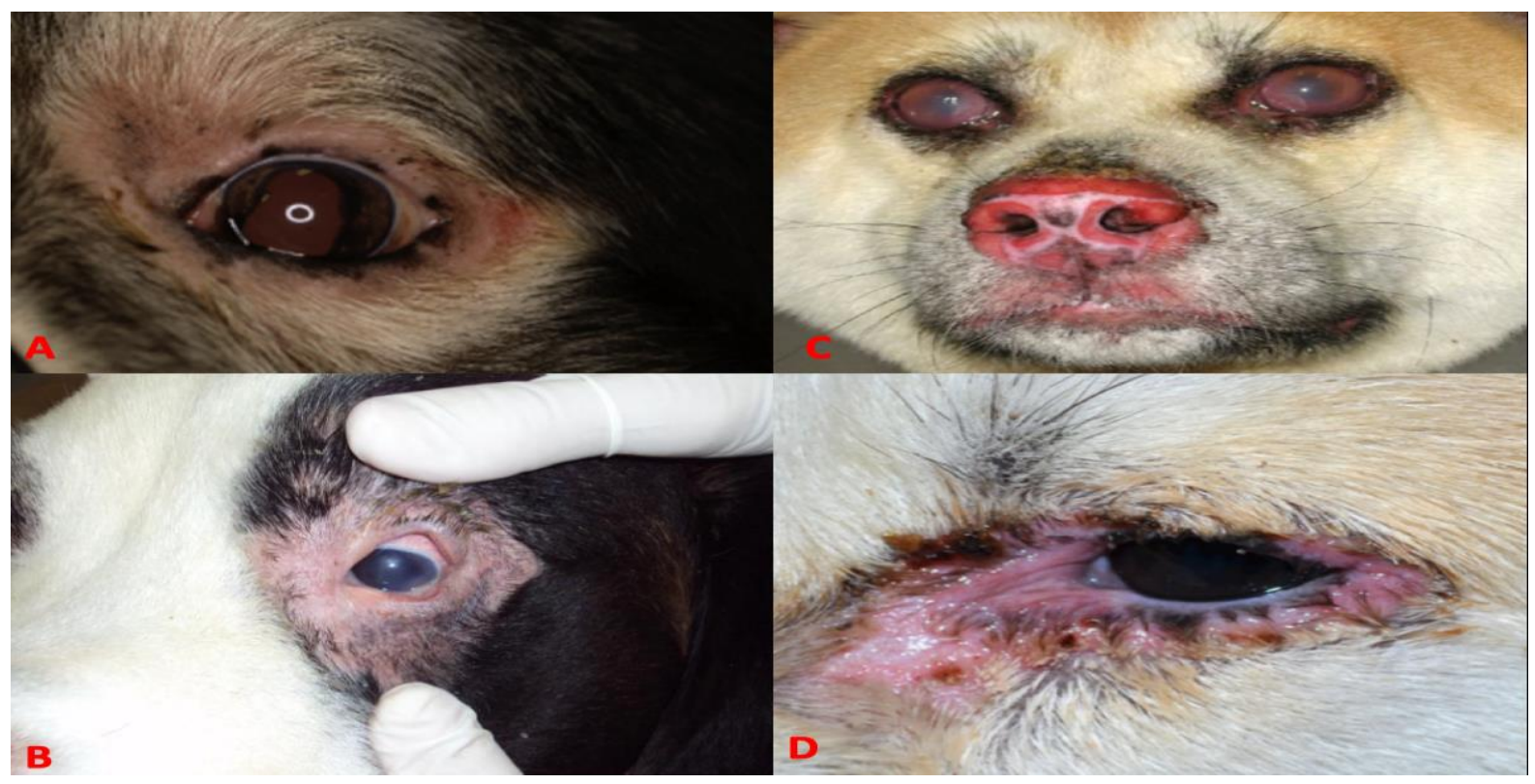

Figure 3. Ophthalmic lesion patterns of dogs with UDS. (A) Palpebral depigmentation with lateral canthus ulceration and dyscoria due to posterior synechia in Bernese Mountain Dog breed (Thomas \& Chahory, 2009) (B) Alopecia and depigmentation of periocular region, besides uveitis and hyperemia of sclera in Saint Bernard breed (FONSECA-ALVES et al., 2014). (C) Bilateral uveitis and severe dermatitis of nasal planum in Chow Chow breed. (D) Periocular erythema, edema and erosions in Siberian Husky breed (THAM et al., 2019).

Neurological and auditory
manifestations can occur, since
inflammatory reactions in meninges have been shown (CARTER et al., 2005), but available data has not proved its relation yet and these alterations are reported more 
frequently in humans. In dogs, the relationship between behavioral changes and UDS is questioned, since the involvement of the nervous system in these animals must be assessed based on an analysis of the cerebrospinal fluid, which reveals pleocytosis (READ et al., 2001).

\section{Diagnosis}

For diagnostic purposes, clinical signs associated with the histopathological findings of skin lesions should be considered (FONSECA-ALVES et al., 2014). Since affected dogs show no changes in hematological and biochemical parameters, the definitive diagnosis should be made based on detailed clinical evaluation and specific tests, including eye function tests and histopathological evaluation of the skin (ZARFOSS et al., 2018). Histopathological examination is essential for diagnosis due to the countless similarities with other diseases with regard to the pattern of injury, such as vitiligo, lupus erythematosus and leishmaniasis (MATIELLO et al., 2004; LAUS et al., 2004; THAM et al., 2019). Samples must be collected from a depigmented, erythematous and/or desquamative region. (ZARFOSS et al., 2018; THAM et al., 2019). Lips and nasal planum are the preferred places, and old and infectious lesions should be avoided.

$$
\text { Histologically, UDS is }
$$

characterized by superficial perivascular inflammation, presenting a robust lichenoid pattern composed by macrophages, lymphocytes, plasma cells and a variable number of neutrophils (Figure 4).

The lesion and the loss of basal keratinocytes, a characteristic interface pattern, are limited or absent. There is partial or total loss of melanocytes with foci of pigmentary incontinence along the dermis. Other patterns, such as epidermal hyperplasia, are usually observed and can be accompanied by erosions, ulcers, neutrophil exocytosis, irregular parakeratosis and crusting (SIGLE et al., 2006; THAM et al., 2019). The progression of the inflammatory process also culminates in the disorganization and dysfunction of collagen fibers, which are responsible for maintaining tissue structure (De LUCIA et al., 2017). These changes are clinically seen as inflamed and depigmented skin and loss of nasal planum architecture.

Histological evaluation of enucleated eyes samples shows lymphoplasmocytic or lymphogranulomatous uveitis. In addition, it is possible to view secondary glaucoma, retinal detachment and retinal atrophy (ZARFOSS et al., 2018). Consequently, UDS should be considered as a differential diagnosis for all dogs with uveitis whose underlying cause cannot be identified by 
physical examination, infectious disease test or systemic imaging.

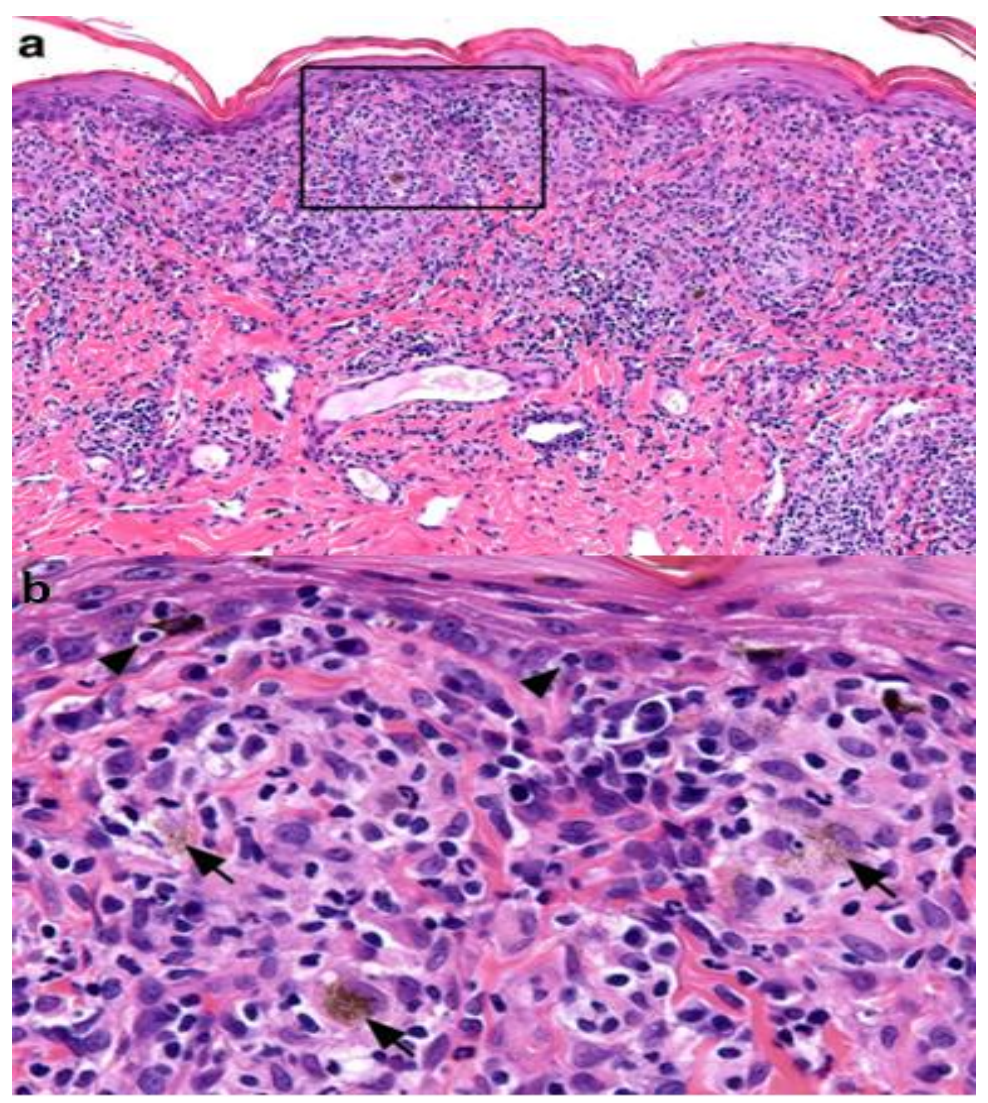

Figure 4. Histopathology of canine uveodermatologic syndrome. Skin biopsy from the face of a dog. (a) Lichenoid dermatitis with inflammatory infiltrate composed by macrophages and lymphocytes with fewer plasma cells and neutrophils. Hematoxylin and eosin, 200x. (b) Inset from image (a) above: lymphocytes (arrow heads) infiltrate the basal layer in low numbers and occasionally appear to surround melanocytes. Melanosomes are present into the dermis, where they appear as a dust-like image inside macrophages (arrows). Hematoxylin and eosin, 400x (THAM et al., 2019).

\section{Therapies}

Since UDS is an immune-mediated disorder and characterized by inappropriate immune response, immunosuppressive and immunomodulating drugs should be used in order to adequately control the autoimmune response (ZARFOSS et al., 2018). The immunosuppressive therapy can be divided in induction phase and maintenance phase. The first one aims at suppressing the inflammatory process, through the administration of topical and systemic corticosteroids in immunosuppressive dosage (GELATT, 2003), while the second one aims at maintaining the lowest dose in order to control the disease and avoid the side effects (ZARFOSS et al., 2018). Topical and oral administration of calcineurin inhibitors and antimetabolites (Table 2) are also used isolated or associated with corticosteroids (FORSTER et al., 1990; 
Oliveira et al., Revista Brasileira de Higiene e Sanidade Animal (v.14, n. 2) p. 247- 261 abr - jun (2020)

ZARFOSS et al., 2018), avoiding complications, such as glaucoma, which in many cases results in loss of vision (SIGLE et al., 2006).

Corticosteroids have potent effects on the skin, where it decreases gene expression associated with inflammatory processes (TIZARD, 2014; OLIVRY et al., 2015). They directly or indirectly affect leukocyte kinetics, phagocytic defenses, cell-mediated immunity, humoral immunity and the production of inflammatory mediators (Tizard, 2014). When there is a good therapy response, the dose should be reduced gradually until the maintenance dose is achieved (MONDKAR et al., 2000; ZARFOSS et al., 2018), and, when the animal has associated glaucoma, the initial treatment can be performed with dorzolamide eye drops and xalatan-based eye drops (Gelatt, 2003).

The prognosis of visual function depends on the time since diagnosis and the start of immunosuppressive treatment, in addition to the intensity of the lesions. If there is no good answer, enucleation can be indicated (SIGLE et al., 2006).

Table 2 - Posology of drugs used in UDS therapy.

DRUG

Prednisolone

Cyclosporine

Azathioprine

Prednisolone $1 \%$ or Dexamethasone

Tacrolimus $0.03 \%$ or $0.1 \%$

\section{$0.1 \%$}

INDUCTION

MAINTENANCE

Oral: $1.0-2.0 \mathrm{mg} / \mathrm{kg} / 24 \mathrm{~h}$

$0.5-2.0 \mathrm{mg} / \mathrm{kg} / 48 \mathrm{~h}$

Oral: $5.0-12.5 \mathrm{mg} / \mathrm{kg} / 24 \mathrm{~h}$

$2.5-5.0 \mathrm{mg} / \mathrm{kg} / 24-48 \mathrm{~h}$

Oral: $1.5-2.5 \mathrm{mg} / \mathrm{kg} / 24 \mathrm{~h}$

$1.5-2.5 \mathrm{mg} / \mathrm{kg} / 48-72 \mathrm{~h}$

Topic: Two to three times/24h One to two times $/ 24 \mathrm{~h}$

Topical ocular therapy consists of eye drops with corticosteroids, which aims to avoid the progression of eye inflammatory response and its consequences (MASSA et al., 2002). Prednisolone acetate $1 \%$ and dexamethasone $0.1 \%$ are potent drugs indicated for topical use due to better intraocular penetration (FINAMOR et al., 2002; PYE, 2009). Regarding this therapy, it is worth mentioning that it is contraindicated in patients with eyes with corneal ulceration, due to the inhibition of healing and possible potentiation of 
infection and collagenolysis. In such cases, systemic steroids can be used in cases of simple, superficial and uninfected corneal ulcers. However, this does not exclude the continuous corneal monitoring (HENDRIX, 2007).

UDS therapy, whether topical or systemic, should be gradually reduced as the clinical signs resolve, being maintained at the maintenance dose, the lowest necessary (FONSECA-ALVES et al., 2014), because, despite its therapeutic action, there are also serious side effects resulting from the prolonged use of these corticosteroids (READ et al., 2001), such as iatrogenic hyperadrenocorticism (ALSAEID et al., 1998). Therefore, the use of other immunosuppressive drugs, such as cyclosporine and azathioprine, is also indicated in order to reduce corticosteroid doses (CARMOZINE et al., 2017; LIMA et al., 2013; ZARFOSS et al., 2018).

UDS has a good response to azathioprine, as it causes a reduction in the number of lymphocytes. However, it is worth mentioning that this medication also has serious side effects, such as hepatopathy and myelosuppression, so it must be associated with corticosteroids, thus decreasing the dose of both (BLACKWOOD et al., 2011; Whitley \& Day, 2011). Azathioprine orally in $\operatorname{dogs}$ are recommended in doses from 1.5 to 2.5 $\mathrm{mg} / \mathrm{kg} /$ day or on alternate days.
Once the lesions are controlled, the dose should be reduced gradually (CAVALCANTI et al., 2005).

Cyclosporine is considered a drug that is effective in allergic skin diseases, especially in cases of atopic dermatitis (FORSYTHE \& PATERSON, 2014). In addition, it is effective in immunemediated eye diseases, having important immunosuppressive and lacrimomimetic properties due to reduction of lymphocyte number (WHITLEY \& DAY, 2011). The usual dose for dogs is 5.0 to 12.5 $\mathrm{mg} / \mathrm{kg} / \mathrm{day}$, which can be divided into two equal doses, and should be administered two hours apart.

Treatment needs to be instituted quickly in order to avoid sequelae such as glaucoma, cataracts, corneal edema and blindness. After the improvement of clinical signs, the medication must be maintained, which is performed with smaller doses and subsequent withdrawl trials (BLACKWOOD et al., 2011; ZARFOSS et al., 2018). The retina also needs evaluation, as the improvement of dermatological lesions has no association with improvements in the retinal lesion (TILLEY \& SMITH, 2003).

\section{Final Considerations}

Although it is known to affect dogs, the rare incidence in the clinic of small animals, associated with the lack of knowledge about the disease, makes an 
early diagnosis difficult. Therefore, it is believed that this review brings important information to veterinarians, in order to favor the identification of this disease, and, consequently, improve the prognosis of dogs affected by UDS.

\section{References}

1. ALSAEID, K.; MAJEED, H.A. Acute rheumatic fever: diagnosis and treatment. Pediatric Annals, v. 27, p.295-300, 1998.

2. ANGLES, J.M.; FAMULA, T.R.; PEDERSEN, N.C. Uveodermatologic (VKHlike) syndrome in American Akita dogs is associated with an increased frequency of DQA1*00201. Tissue Antigens, v. 66, n. 6, p. 656-665, 2005.

3. ASAKURA, S.; TAKAHARA, T.; ONISHI, T. Vogt-Koyanagi-Harada syndrome (uveitis diffusa acuta) in the Dog. Japanese Journal of Veterinary Medicine. v. 673, p. 449-455, 1977.

4. BLACKWOOD, S.E.; BARRIE, K.P.; PLUMMER, C.E.; TAYLOR, D.; NUNNERY, C. M.; SELTZER, J.D.; BEN-SHLOMO, G.; BROOKS, D.E. Uveodermatologic syndrome in a rat terrier. Journal of the American Animal Hospital Association, v. 47, n. 4, p. 56-63, 2011.

5. BOYD, S.R.; YOUNG, S.; LIGHTMAN, S. Immunopathology of the noninfectious posterior and intermediate uveitides. Survey of Ophthalmology, v. 46, n. 3, p. 209-233, 2001.

6. CARMOZINE, A.G.D.; JORGE, A.T.; HONSHO, C.S.; DIAS, F.G.G.; PEREIRA, L.F. Complicações oftalmológicas e dermatológicas de um cão com síndrome uveodermatológica: acompanhamento durante 9 meses. In: $17^{\circ}$ Congresso Nacional de Iniciação Científica, 2017, São Paulo. Anais do Congresso Nacional de Iniciação Científica, São Paulo: SEMESP, São Paulo, 2017, p. 1-11.
7. CARTER, WALLACE J.; CRISPIN, SHEILA M.; GOULD, DAVID J.; DAY, MICHAEL J. An immunohistochemical study of uveodermatologic syndrome in two Japanese Akita dogs. Veterinary Ophtalmology, v. 8, n. 1, p. 17-24, 2005.

8. CAVALCANTI, A.O.C; SAMPAIO, G.R; MIAN, G.F. Síndrome Uveodermatológica: Revisao de Literatura: Uveodermatological syndrome: literature review. Revista de Educação Continuada - CRMV-SP: Revisão e Ensaio , Lavras, MG, v. 8, n. 2, p. 98-108, dez./2005

9. COTTELLL, B.D.; BARNETT, K.C. Harada's disease in the Japanese Akita. Journal of Small Animal Practice, v. 28, n. 6, p. 517-521, 1987.

10. DE LUCIA, M.; MEZZALIRA, G.; BARDAGI, M.; FONDEVILA, D.M.; FABBRI, E.; FONDATI, A. A retrospective study comparing histopathological and immunopathological features of nasal planum dermatitis in 20 dogs with discoid lupus erythematosus or leishmaniosis. Veterinary Dermatology, v. 28, p. 200-e46, 2017.

11. FINAMOR, L.P.; JUNIOR, F.F.; MUCCIOLI C. Corticoterapia e uveítes. Arquivo Brasileiro de Oftalmologia, v.65, n.4, p.56-59, 2002.

12. FONSECA-ALVES, C.E.; NOBREGA, J.; LAUFER-AMORIM, R.; DE MOURA, V.M. B.D. Síndrome uveodermatológica canina: revisão de literatura. Revista de Ciência Veterinária e Saúde Pública, v. 1, n. 2, p. 125-134, 2014

13. FORSTER, D.J.; CANO, M.R.; GREEN, R.L.; RAO, N.A. Echographic features of the Vogt- Koyanagi-Harada syndrome. Archives of Ophthalmology, v.108, n.10, 1990.

14. FORSYTHE, P.; PATERSON, S. Ciclosporin 10 years on: indications and efficacy. Veterinary Record, v. 174 (Suppl 2), p. 13-21, 2014. 
15. GELATT, K.N.; OPHTHALMOLOGY, V.; EDITION, F. Canine Anterior Uvea: Diseases and Surgery. Essentials of Veterinary Ophthalmology, p. 276-300, 2014.

16. GODOY, C.A.L.; SAFATLE, A.M.V.; TEIXEIRA, A.L.; SOUZA, M.S.B.; BARROS, P.S.M. Uveodermatological syndrome in a cocker-poodle mixed breed dog. Archives of Veterinary Science, v.8, n.1, p.29-33, 2003.

17. HENDRIX, D.V.H. Canine Anterior Uvea: Diseases and Surgery. In: Essentials Veterinary Ophtalmology. 4 ed, Iowa: Black Publishing, 2007. Cap. 13, p. 275-300.

19. HERRERA; DUCHENE. Uveodermatological syndrome (VogtKoyanagi-Harada-like syndrome) with generalized depigmentation in a Dachshund. Veterinary Ophthalmology, v. 1, n. 1, p. 47$51,1998$.

20. HORIKAWA, T.; VAUGHAN, R.K.; SARGENT, S.J.; TOOPS, E.E.; LOCKE, E.P. Pathology in practice. Journal of the American Veterinary Medical Association, v. 253, n. 8, p. 997-1000, 2013.

21. KANG, M.H.; LIM, C.Y.; PARK, H.M. Uveodermatologic syndrome concurrent with keratoconjunctivitis sicca in a miniature poodle dog. Canadian Veterinary Journal, v. 55 , n. 6, p. 585-588, 2014.

22. KIBAR, M.; ASLAN, O.; ARSLAN, K. Uveadermatological syndrome (VogtKoyanagi-Harada- like syndrome) with depigmentation in a Siberian Husky. Revue de Medecine Veterinaire, v. 165, n. 1-2, p. 5760, 2014.

23. LAUS, J.L. SOUSA, M.G.; CABRAL, V.P.; MAMEDE, F.V.; TINUCCI-COSTA, M. Uveodermatologic syndrome in a Brazilian Fila dog. Veterinary Ophthalmology, v.7 n.3, p.193-196, 2004.

24. LIMA, E.R.; FUKAHORI, F.L.P.; DIAS, M.B.M.C.; SILVA, V.C.L.; REGO, M.S.A.; FERREIRA, M.A.Q.B. Síndrome úveodermatológica em um canino da raça akita - relato de caso. Acta Veterinaria Brasilica, Pernambuco, v. 7, p. 199-201, 2013.
25. MASSA, K.L.; GILGER, B.C.; MILLER, T.L.; DAVIDSON, M.G. Causes of uveitis in dogs: 102 cases (1989-2000). Veterinary Ophthalmology, v. 5, n. 2, p. 93-98, 2002.

26. MATIELLO, M.; CARVALHO, H.C.; ALVARENGA, H.; ALVARENGA, R.M.P. Síndrome de Vogt-Koyanagi-Harada. Caderno Brasileiro de Medicina, v.17, 2004.

27. MONDKAR, S.V.; BISWAS, J.; GANESH, S.K. Analysis of 87 cases with Vogt-Koyanagi-Harada disease. Japanese Journal of Ophthalmology, v.44, n.3, p.296301, 2000.

28. O'KEEFE, G.A.D.; RAO, N.A. VogtKoyanagi-Harada disease. Survey of Ophthalmology, v. 62, n. 1, p. 1-25, 2017.

29. OLIVRY, T.; DEBOER, D.J.; FAVROT, C.; JACKSON, H.A.; MUELLER, R.S.; NUTTALL, T.; PRÉLAUD, P. Treatment of canine atopic dermatitis 2015 updated guidelines from the International Committee on Allergic Diseases of Animals (ICADA). BMC Veterinary Research, v. 11, n. 1, p. 115, 2015.

30. PYE, C.C. Uveodermatologic syndrome in an Akita. The Canadian Veterinary Journal, v.50, p. 861-864, 2009.

31. READ, R.W.; HOLLAND, G.N.; RAO, N.A.; TABBARA, K.F.; OHNO, S.; ARELLANES- GARCIA, J.; PIVETTIPEZZI, P.; TESSLER, H.H.; USUI, M. Revised diagnostic criteria for Vogt-KoyanagiHarada disease: report of an international committee on nomenclature. American Journal of Ophthalmology, v.131, n.5, p.647652, 2001.

32. RHODEN, N.C. Pawprints in Japan Dogs in myth and History. 1th ed. California: Fire Lake Press, 2002, 131p.

33. SIGLE, K.J.; MCLELLAN, G.J.; HAYNES, J.S.; MYERS, R.K.; BETTS, D.M. Unilateral uveitis in a dog with uveodermatologic syndrome. Journal of the American Veterinary Medical Association, v.228, n. 4, p.543-548, 2006. 
34. SUÁREZ, P.; HERNÁNDEZ, H. Síndrome uveodermatológico canino: reporte de caso. Journal of Agriculture and Animal Sciences, v.1, n. 1, p. 70-76, 2012.

35. THAM, H.L.; LINDER, K.E.; OLIVRY, T. Autoimmune diseases affecting skin melanocytes in dogs, cats and horses: vitiligo and the uveodermatological syndrome: a comprehensive review. BMC Veterinary Research, v. 15, n. 1, p. 1-17, 2019.

36. THOMAS, O.; CHAHORY, S. A case of uveodermatologic syndrome in a Bernese Mountain dog. Pratique médicale et chirurgicale de l'animal de compagnie, v.44, p.55-61, 2009.

37. TILLEY, L.P.; SMITH, F. W.K. Consulta Veterinária em 5 minutos espécies canina e felina. 2. ed. São Paulo: Manole, 2003. 1423 p.

38. TIZARD, I.R. Imunologia veterinária: introdução. 9. ed. São Paulo: Elsevier, 533p., 2014.

39. TRBOLOVA, A.; KOZAK, I.; SEVCIKOVA, Z.; BALICKY, I.; LEDECKY, V.; CAPIK, I. The occurrence of canine VogtKoyanagi-Harada as a syndrome in the Rottweiler. Folia Veterinaria, v. 47, n.4, p.193-196, 2003.

40. WHITLEY, N.T.; DAY, M.J. Immunomodulatory drugs and their application to the management of canine immunemediated disease. Journal of Small Animal Practice, v. 52, n. 2, p. 70-85, 2011.

41 YAMAKI, K.; TAKIYAMA, N.; ITHO, N.; MIZUKI, N.; SEIYA, M.; SINSUKE, W.; HAYAKAWA, K.; KOTANI, T. Experimentally induced Vogt-KoyanagiHarada disease in two Akita dogs. Experimental Eye Research, v. 80, n. 2, p. 273-280, 2005.

42. YAMAKI, K.; GOCHO, K.; HAYAKAWA, K.; KONDO, I.; SAKURAGI, S. Tyrosinase Family Proteins Are Antigens Specific to Vogt-Koyanagi-Harada Disease. The Journal of Immunology, v. 65, n. 12, p. 7323-7329, 2000.
43. ZARFOSS, M.K.; TUSLER, C.A.; KASS, P.H.; MONTGOMERY, K.; LIM, C.C.; MOWAT, F.; THOMASY, S.M. Clinical findings and outcomes for dogs with uveodermatologic syndrome. Journal of the American Veterinary Medical Association, v. 252, n. 10, p. 1263-1271, 2018. 